\title{
ANALISIS KETERSEDIAAN INPUT UNTUK MENYELENGGARAKAN PONEK DI RUMAH SAKIT UMUM SWASTA DI KOTA DENPASAR
}

\author{
Ni Wayan Purnama Dewi*, Ni Made Sri Nopiyani \\ Program Studi Kesehatan Masyarakat Fak. Kedokteran Universitas Udayana \\ *email: pdpurnama@gmail.com
}

\begin{abstract}
ABSTRAK
Rumah sakit Pelayanan Obstetri Neonatal Emergency Komprehensif(PONEK) 24 Jam merupakan bagian dari sistem rujukan pelayanan kedaruratan maternal dan neonatal yang sangat berperan dalam menurunkan angka kematian ibu dan bayi baru lahir. Rumah Sakit Umum Swasta di Kota Denpasar telah terlatih PONEK sejak tahun 2015, namun belum pernah dilakukan evaluasi sehingga belum diketahui ketersediaan input untuk penyelenggaraan PONEK di RSU Swasta di Kota Denpasar. Penelitian ini bertujuan untuk mengetahui ketersediaan input PONEK di RSU Swasta di Kota Denpasar. Penelitan ini merupakan studi evaluatif terhadap Rumah Sakit Swasta terlatih PONEK di Kota Denpasar. Pengumpulan data dilakukan dengan metode observasi, studi dokumentasi dan wawancara mendalam di RSU Puri Raharja dan RSU Prima Medika. Teknik pengambilan sampel pada penelitian ini dengan menggunakan metode purposive sampling.Observasi dilakukan di area cuci tangan dan pemrosesan alat di unit maternal dan neonatal, area resusitasi dan stabilisasi di ruang obstetri dan neonatus di UGD, ruang bersalin, kamar operasi, unit perawatan intensif, area laktasi dan area pencucian inkubator. Wawancara mendalam dilakukan kepada 4 orang informan kedua rumah sakit yang terdiri dari 1 orang kepala bidang pelayanan medik dan 1 orang ketua tim PONEK. Hasil penelitian menunjukkan ketersediaan SDM di RSU Swasta di Kota Denpasar masih kurang. Di rumah sakit baru tersedia Tim PONEK sesuai standar Tim PONEK esensial. Dana penyelenggaraan PONEK telah tersedia yang digunakan untuk penyediaan sarana, prasarana dan peningkatan kapasitas SDM. Untuk ketersediaan sarana dan prasarana masih kurang. Terdapat 2 kendala penyediaan sarana dan prasarana yakni terkait keterbatasan tempat dan dana. Pedoman penyelenggaraan PONEK 24 jam di rumah sakit dan SPO terkait pelayanan kegawatdaruratan maternal dan neonatal terdapat di rumah sakit dan telah disosialisasikan. Kebijakan pendukung pelayanan PONEK di rumah sakit telah ada dalam bentuk SK Direktur RS tentang Pembentukan Tim PONEK RS dan pemberlakukan Pedoman Pelayanan PONEK di Rumah Sakit. Dapat disimpulkan bahwa ketersediaan input dalam penyelenggaraan PONEK di RSU Swasta di Kota Denpasar belum optimal. Diperlukan adanya peningkatanSDM, sarana dan prasarana serta peninjauan kembali standar prosesdur operasional.
\end{abstract}

Kata kunci: Ketersediaan Input, Penyelenggaraan PONEK, RSU Swasta

\begin{abstract}
Hospital with 24 hours Comprehensive Emergency Neonatal Obstetric Services (PONEK) is part of referral system for maternal and neonatal emergency services. This services plays pivotal role in reducing maternal and newborn mortality. Private hospitals in Denpasar have been received PONEK training since 2015, however there was no evaluation has been conducted regarding input availability during its implementation in private hospitals in Denpasar. Therefore, this study aims to find out the availability of PONEK inputs in private hospitals. This research is an evaluative study. Data collection was carried out by observation, study documentation, and indepth interviews at Puri Raharja Hospital and Prima Medika Hospital. This study was using purposive sampling method. Observation was carried out in washing hand areas and processing equipment in maternal and neonatal units and stabilization areas in obstetric and neonatal rooms in the emergency room, delivery room, operating room, intensive care unit, area lactation and incubator washing area. In-depth interviews were conducted with 4 informants from the two hospitals consisting of 1 head of medical services and 1 chief of the PONEK team. Study found that the availability of human resources in private hospitals in the city of Denpasar is still lacking. Team is available according to the standards of the essential PONEK Team. Funds for the implementation of PONEK are available which are used to provide facilities, infrastructure and increase human resource capacity. The availability of facilities and infrastructure is also still lacking. There are 2 obstacles in the provision of facilities and infrastructure which are related to limited space and funds. Guidelines for implementing 24-hour PONEK in hospitals and Standard Operating Procedures related to maternal and neonatal emergency services are available in hospitals and have been socialized. There is Decree of the Hospital Director regarding the Formation of the PONEK Hospital Team as supporting policy. It can be concluded that the availability of inputs in the implementation of PONEK in Private Hospitals in Denpasar City has not been optimal. There is a need to improve HR, facilities and infrastructure as well as a review of operational process standards.
\end{abstract}

Keywords: Input Availability, Organizing PONEK, Private Public Hospital 


\section{PENDAHULUAN}

Pelayanan obstetri dan neonatal regional merupakan upaya penyediaan pelayanan bagi ibu dan bayi baru lahir secara terpadu dalam bentuk Pelayanan Obstetri Neonatal Emergensi Komprehensif (PONEK) di rumah sakit dan Pelayanan Obstetri Neonatal Emergensi Dasar (PONED) di Puskesmas. Rumah sakit PONEK 24 Jam merupakan bagian dari sistem rujukan pelayanan kedaruratan maternal dan neonatal yang sangat berperan dalam menurunkan angka kematian ibu dan bayi baru lahir (Kemenkes RI,2013)

Hingga pertengahan bulan Desember 2015, angka kematian ibu di Provinsi Bali berjumlah 60 kasus. Sedangkan untuk angka kematian neonatushingga desember 2015 sejumlah 252kasus. Ditinjau dari tempat kematian ibu pada tahun 2015, dari 60 kasus kematian yang ada di Provinsi Bali, $95 \%$ meninggal di Rumah Sakit dengan rincian 70\% meninggal di RSU Pemerintah dan 28\% meninggal di RS Swasta. (Dinas Kesehatan Provinsi Bali,2015)

Pemanfaatan pelayanan kesehatan ibu dan anak oleh masyarakat tidak hanya pada RSU Pemerintah saja tetapi juga pada RSU Swasta.Sehingga penyelenggaraan PONEK sangat penting untuk dilaksanakan di RS Swasta. Pada Pedoman Penyelenggaraan PONEK 24 Jam di Rumah Sakit dicantumkan bahwa kunci keberhasilan PONEK terdapat pada ketersediaan input meliputi ketersediaan tenaga kesehatan yang sesuai kompetensi, prasarana, sarana dan manajemen (Kemenkes RI, 2013)
Program PONEK merupakan salah satu standar sasaran dalam akreditasi rumah sakit yang termasuk di dalam sasaran Millenium Development Goal's pertama (SMDG's I) yakni penurunan angka kematian bayi dan peningkatan kesehatan ibu. Dari 6 RS yang terlatih PONEK di Kota Denpasar, 3 RS diantaranya telah terakreditasi dan 3 RS lainnya belum terakreditasi. Berdasarkan pada SMDG's I dan standar dalam Pedoman Penyelenggaraan PONEK 24 Jam di Rumah Sakit peneliti tertarik untuk melihat variasi ketersediaan input secara kuantitas dan kualitas dengan melakukan analisis terhadap RSU Swasta terlatih PONEK yang telah terakreditasi dan belum terakreditasi di Kota Denpasar.

\section{METODE}

Penelitan ini merupakan studi evaluatif terhadap Rumah Sakit Swasta terlatih PONEK di Kota Denpasar.Pengumpulan data dilakukan dengan metode observasi, studi dokumentasi dan wawancara mendalam. Aspek yang diteliti adalah ketersediaan input dalam pelaksanaan PONEK di rumah sakit tersebut. Penelitian dilakukan di RSU Swasta terlatih PONEK di Kota Denpasar yaitu RSU Puri Raharja dan RSU Prima Medika.Penelitian berlangsung dari Bulan Januari sampai dengan bulan Mei 2016.Teknik pengambilan sampel pada penelitian ini dengan metode purposive sampling yang berarti sampel penelitian dipilih atas pertimbangan tertentu. Pertimbangan yang digunakan adalah status akreditasi rumah sakit dan pelayanan unggulan rumah sakit. 
Berdasarkan pertimbangan tersebut akan dilakukan analisis ketersediaan input pada sampel RSU Swasta terlatih PONEK yang telah terakreditasi dan RSU Swasta terlatih PONEK yang belum terakreditasi. Sesuai dengan metode sampling yang digunakan maka sampel pada penelitian ini adalah RSU Puri Raharja dan RSU Prima Medika.

Informan pada penelitian ini dipilih dengan metode purposive sampling, yaitu teknik pengambilan sampel dengan pertimbangan bahwa informan tersebut dianggap paling tahu tentang apa yang diharapkan oleh peneliti (Sugiyono, 2012). Informan dipilih berdasarkan asas kecukupan dan kesesuaian. Informan pada penelitian ini adalah Ketua Tim PONEK dan bagian manajemen khususnya bidang pelayanan medik di RSU Puri Raharja dan RSU Prima Medika yang masing-masing berjumlah 1 orang. Sehingga informan pada penelitian ini berjumlah 4 orang

\section{HASIL}

\section{Ketersediaan Sumber Daya Manusia}

Tabel 1. Ketersediaan SDM PONEK di RS Swasta di Kota Denpasar

\begin{tabular}{lccccc}
\hline \multicolumn{1}{c}{ Rumah Sakit } & Nilai Aktual & $\begin{array}{l}\text { Nilai } \\
\text { yang dibutuh } \\
\text { kan }\end{array}$ & Persentase (\%) & Kategori \\
\hline $\begin{array}{l}\text { RSU } \\
\text { Raharja }\end{array}$ & Puri & 6 & 15 & 40 & Kurang \\
$\begin{array}{l}\text { RSU } \\
\text { Medika }\end{array}$ & Prima & 6 & 15 & 40 & Kurang \\
\hline
\end{tabular}

Pada tabel di atas menunjukkan
bahwa ketersediaan SDM untuk menyelenggarakan PONEK di 2 RSU Swasta di Kota Denpasar masih kurang. Berdasarkan Surat Keputusan (SK) Direktur Rumah Sakit Puri Raharja dan RSU Prima Medika, SDM yang masuk dalam SK Tim PONEK di rumah sakit terdiri dari tenaga kesehatan sesuai kriteria essensial yakni 2 orang tenaga dokter spesialis kebidanan dan kandungan, 2 orang dokter spesialis anak, 2 orang dokter umum, 3 orang bidan (1 koordinator dan 2 penyelia) dan 2 orang perawat. Tambahan SDM yang telah masuk ke dalam tim PONEK yaitu 2 orang dokter spesialis anastesi dan tenaga administrasi.

Dari segi kompetensi SDM PONEK di rumah sakit, belum semua SDM yang masuk dalam tim PONEK telah terlatih PONEK. Namun, SDM PONEK telah mendapatkan pelatihan dasar dan pernah mengikuti sosialisasi PONEK.

"Untuk mendukung itu semua kami pernah mengikuti bukan pelatihan sih jadi workshop sehari apa ya namanya lupa saya workshop resusitasi intinya sih itu tentang RJPnya bayi, cuman memang untuk pelatihan murni yang perlu memakan waktu beberapa hari memang belum. Jadi kami baru mengikuti workshop atau seminar. Pelatihan ponek baru ikut kemarin terdiri dari 2 kelas tim maternal dan 
neonatal. Jadi bidannya terpecah dia ada yang di kelas maternal ada yang di kelas neonatal. Yang murni untuk pelatihan kegawatdaruratan neonatalnya sendiri belum jadi lebih ke NICU PICU gitu ya. Rencananya sih tahun depan, mungkin diklat nanti yang mengatur"(PR 1)

"Selain pelatihan PONEK, SDM PONEK di RS kami telah mengikuti beberpa pelatihan terkait kegawatdaruratan obstetri dan neonatologi selain itu tim di IGD juga telah terlatih ATCLS dan ACLS"(PM 2)

\section{Ketersediaan Dana}

RSU Puri Raharja dan RSU Prima Medika telah memiliki anggaran untuk menunjang terlaksananya pelayanan kesehatan di rumah sakit. Di RSU Prima Medika, telah tersedia dana untuk penyelenggaraan PONEK dan dimanfaatkan untuk pemenuhan sarana dan prasarana serta peningkatan kapasitas SDM di rumah sakit. Sedangkan di RSU Puri Raharja anggaran pelayanan yang ada masih direncanakan secara umum belum khusus sebagai dana penunjang pelayanan PONEK. Pemberian anggaran di rumah sakit disesuaikan dengan prioritas kebutuhan di masing-masing pelayanan. Walaupun demikian, penyediaan dana terkait penyelenggaraan

Tabel 2. Sarana prasarana pada Unit Maternal di RSU Swasta di Kota Denpasar

\begin{tabular}{lcccc}
\hline Rumah Sakit & Nilai Aktual & $\begin{array}{c}\text { Nilai yang } \\
\text { dibutuhkan }\end{array}$ & Persentase (\%) & Kategori \\
\hline $\begin{array}{l}\text { RSU Puri } \\
\text { Raharja }\end{array}$ & 115 & 157 & 73,25 & Kurang \\
$\begin{array}{l}\text { RSU Prima } \\
\text { Medika }\end{array}$ & 117 & 157 & 74,52 & Kurang \\
\hline
\end{tabular}

PONEK telah direncanakan secara bertahap di dalam rencana anggaran

"Kalau itu setahu saya sih, ga tahu juga di manajemen. Kalau kita perlu alat apa kita melakukan pengamprahan, nanti kalau memang bisa disediakan akan disediakan.memang ada sih pendanaan itu cuman mungkin secara renstra masih gabung, masih umum sifatnya belum khusus ini PONEK dananya per tahun sekian."(PR1)

"Ada dana untuk penyelenggaraan PONEK yang digunakan untuk pelayanan kemudian melengkapi sarana dan prasarana, dan yang telah kami laksanakan seperti melakukan peningkatan kapasitas SDM. Sampai saat ini dana rs untuk menunjang pelayanan ponek cukup, dan untuk pemberian jasa pelayanan SDM diberikan berdasarkan tindakan petugas kepada pasien,tidak ada jaspel khusus PONEK"(PM 2)

\section{Ketersediaan Sarana dan Prasarana}

Pemantauan ketersediaan sarana dan prasarana dilakukan pada 2 unit pelayanan yakni unit maternal dan neonatal. rumah sakit. 
Pemantauan ketersediaan input unit maternal dilakukan di beberapa ruangan sesuai yang tercantum dalam daftar tilik meliputiUnit Gawat Darurat, ruang bersalin, area pemrosesan alat dan pencegahan infeksi, ruang intensif pasien eklampsi/sepsis dan kamar operasi.Ketersediaan sarana prasarana pada unit maternal masih kurang. Belum tersedia area stabilisasi dan resusitasi di unit obstetri/UGD di kedua rumah sakit. Pasien dengan kegawatdaruratan maternal langsung diarahkan menuju ruang

Tabel 3. Sarana prasarana pada unit neonatal di RSU Swasta di Kota Denpasar

\begin{tabular}{lccccc}
\hline Rumah Sakit & Nilai Aktual & $\begin{array}{c}\text { Nilai yang } \\
\text { dibutuhkan }\end{array}$ & Persentase (\%) & Kategori \\
\hline $\begin{array}{l}\text { RSU } \\
\text { Raharja }\end{array}$ & Puri & 91 & 142 & 64,08 & Kurang \\
$\begin{array}{l}\text { RSU } \\
\text { Medika }\end{array}$ & Prima & 133 & 142 & 90,48 & Kurang \\
\hline
\end{tabular}

Ketersediaan sarana prasarana pada unit neonatologi masih kurang. Belum tersedia unit perawatan intensif dan area pencucian inkubator di RSU Puri Raharja. Keterbatasan ruangan dan lahan menjadi kendala rumah sakit untuk menyediakan ruangan tersebut.

Secara keseluruhan ketersediaan sarana dan prasarana di RSU Swasta di Kota Denpasar masih kurang. Sebagian

Tabel 4. Ketersediaan Sarana dan Prasarana PONEK di RSU Swasta di Kota Denpasar

\begin{tabular}{llllll}
\hline Rumah Sakit & Nilai Aktual & $\begin{array}{l}\text { Nilai } \\
\text { dibutuh } \\
\text { kan }\end{array}$ & yang & Persentase (\%) & Kategori \\
\hline RSU Puri Raharja & 206 & 299 & 68,90 & Kurang \\
RSU Prima & 250 & 299 & 83,61 & Kurang \\
Medika & & & & \\
\hline
\end{tabular}


Vol. 5 No. $1: 9$ - 8

"Ya sekarang kita tinggal kekurangan NICU

PICUnya aja, kalau ICU kita kan sudah punya dan OK yang beroperasi 24 jam kita ada terus UGD kita punya juga"(PR1)

Terdapat 2 kendala dalam pemenuhan sarana dan prasarana penyelenggaraan PONEK di rumah sakit yakni ketersediaan tempat dan dana.

Oleh karena keperluan biaya yang cukup tinggi, penyediaan sarana dan prasarana direncanakan secara bertahap sesuai dengan prioritas kebutuhannya.

"Kendalanya mungkin kita bukan di SDMnya tapi lebih di sarana prasarananya, karena memang kita tahu peralatan itu semuanya yang membutuhkan biaya yang tinggi itu terkait itu juga penyediaan bangunannya juga"(PR1)

"Kembali lagi kendala kami terkait dengan penyediaan dana, tapi kami tetap berupaya dengan melengkapi perlengkapan secara bertahap."(PM2)

Meskipun ketersediaan sarana dan prasarana masih di bawah standar, hasil wawancara menunjukan bahwa sarana dan prasarana telah mampu menunjang pelayanan kegawatdaruratan maternal dan neonatal di rumah sakit.

"Kalau sarana penunjang sudah optimal sudah menunjang, cuman karena lokasi saja yang masih menjadi kendala dari segi PONEK, tapi dari segi kinerja mau ditaruh di barat atau di timur, posisi itu SDM yang menyesuaikan, kalau sarana prasarana ada"(PM1)

\section{Ketersediaan Pedoman}

Ketersediaan pedoman dilihat dari adanya pedoman penyelenggaraan PONEK 24 Jam di rumah sakit dan standar prosesdur operasional (SPO) dalam memberikan pelayanan seperti SPO
Eklampsi, SPO Perdarahan, SPO Infeksi/Sepsis.

Pedoman PONEK yang ada telah disosialisasikan kepada unit terkait penyelenggaraan PONEK secara resmi maupun penyampaian secara personal antar petugas. Dalam pelaksanaan penggunaan SPO di rumah sakit masih mengalami beberapa kendala terkait keseragaman pelaksanaannya dan kesesuaian dengan kondisi di rumah sakit. "Pedoman PONEK ada dan sudah disosialisasikan penanganan kegawatdaruratan juga sudah sesuai SPO"(PM2)

"Harusnya secara resmi khan kita di aula mengundang beberapa orang dari pihak manajemen, teman-teman lapangan juga yang harus tahu pelayanan PONEK seperti ini secara itu belum, tapi saya mencoba mensosialisasikan dari mulut ke mulut jadi saya ketemu dengan mereka saya kasih tahu bahwa kita sudah ada PONEK disini ada pelayanan PONEKnya jadi PONEK itu seperti ini artinya ya mungkin skup ngobrolngobrol begini lah secara resmi belum tapi sosialisasi personal sudah pas kita ketemu pas kita ke ruangan karena saya dalam tim supervisi jadi pas kita supervisi saya sampaikan ada pelayanan PONEK disini"(PR1)

\section{Kebijakan Pendukung Pelaksanaan PONEK}

Pada RSU Puri Raharja dan RSU Prima Medika telah terdapat kebijakan pendukung penyelenggaraan PONEK di rumah sakit. Bentuk kebijakan pendukung berupa surat keputusan direktur tentang pembentukan tim PONEK dan adanya 
kebijakan penggunaan Pedoman PONEK di rumah sakit.

"SK tim PONEK ada dan kebijakan tentang PONEK tersendiri ada, struktur tim juga ada, ada timnya ada struktur PONEKnya, strukturnya khan ada dari manajemennya, dokternya,bidannya"(PR1)

"Komitmen pimpinan
menyelenggarakan PONEK yang pertama
tentu dengan membentuk Tim PONEK.
Dilanjutkan dengan membuat kebijakan
pelayanan PONEK."(PM2)

Sesuai dengan hasil wawancara mendalam disampaikan bahwa kedua rumah sakit telah ada SK Direktur tentang pembentukan tim PONEK di rumah sakit. Bentuk kebijakan pendukung lainnya dengan adanya komitmen dan menyediakan dana untuk melaksanakan pelatihan PONEK dan pemenuhan sarana dan prasarana.

"Dukungan pimpinan bagus, beliau mendukung sekali. Apa yang mau kita ajukan kita list, terus kaya kemarin disuruh membuat komitmen,komitmen manajemen karena itu khan masalah pembiayaan pengaturan tempat, saya buatkan dan ditandatangani dirut dan direktur pelayanan"(PR1)

\section{DISKUSI}

Berdasarkan hasil observasi penelitian yang dilakukan di RSU Puri Rahara dan RSU Prima Medika, ketersediaan SDM di kedua rumah sakit masih kurang untuk memenuhi standar Tim PONEK ideal.SDM yang tersedia untukmenyelenggarakan PONEK di kedua rumah sakit baru sesuai dengan tim essensial ditambah dengan dokter spesialis anastesi dan petugas administrasi. Menurut hasil penelitian Simbolon, dkk (2011) yang berjudul Determinan Pelayanan Kesehatan Ibu dan Anak di Rumah Sakit Pemerintah Indonesia (Analisis Data Riset Fasilitas Kesehatan 2011), rumah sakit yang memiliki tim PONEK yang tidak lengkap mempunyai risiko 1,78 kali untuk memiliki kinerja pelayanan yang kurang optimal dibandingkan dengan rumah sakit yang memiliki tim PONEK lengkap. Sehingga untuk dapat mengoptimalkan pelayanan kesehatan ibu dan anak khususnya PONEK di rumah sakit maka perlu upaya untuk dapat melengkapi tim PONEK sesuai standar yang ada.

Tim PONEK di RSU Swasta di Kota Denpasar belum tersedia di setiap shift jaga dan beberapa SDM khususnya dokter spesialis masih on call. Menurut pendapat rumah sakit, walaupun Tim PONEK belum tersedia dalam setiap shift jaga dan tenaga dokter spesialis masih on call kondisi ini tidak menghambat kegiatan pelayanan kegawatdaruratan maternal dan neonatal di rumah sakit. Walaupun belum terlatih PONEK, dokter umum, bidan dan perawat yang berjaga di UGD maupun setiap ruangan telah memiliki kompetensi dasar penanganan kegawatdaruratan selain itu dokter spesialis dapat segera tiba di RS ketika terjadi kasus kegawatdaruratan maternal dan neonatal. Pendapat tersebut berbeda dengan hasil penelitian Simbolon,dkk yang menyatakan bahwa kesiapsiagaan tim PONEK 24 jam dengan kemampuan clinical risk diperlukan jaga on-site untuk mempercepat penanganan masalah kegawatdaruratan. 
Dana untuk menyelenggarakan PONEK telah tersedia di RSU Swasta di Kota Denpasar. Walaupun ketersediaan dana ini berbeda di setiap rumah sakit. Perbedaan ini kemungkinan dipengaruhi oleh jumlah kunjungan maternal dan neonatal serta layanan unggulan masingmasing rumah sakit. Jumlah kunjungan pasien maternal dan neonatal di RSU Puri Raharja lebih sedikit dibandingkan dengan RSU Prima Medika. Selain itu pelayanan obstetri merupakan pelayanan unggulan di RSU Prima Medika.

Terdapat 2 kendala yang dihadapi oleh rumah sakit untuk memenuhi ketersediaan sarana dan prasarana sesuai standar PONEK yakni keterbatasan lahan/ruangan serta keterbatasan dana. Walaupun memiliki keterbatasan dalam penyediaan sarana dan prasarana, rumah sakit tetap berupaya untuk memanfaatkan lahan yang ada dengan melakukan beberapa perbaikan secara bertahap. Pelayanan kesehatan ibu dan anak dengan standar PONEK baru mulai diterapkan oleh rumah sakit pada tahun 2015 sehingga perlu waktu untuk dapat menyediakan sarana dan prasarana PONEK sesuai standar.

Pedoman diperlukan sebagai acuan dalam pelaksanaan pelayanan PONEK di rumah sakit. Dalam pedoman PONEK disebutkan salah satu kriteria umum rumah sakit PONEK yakni ada Standar Prosedur Operasional (SPO) penerimaan dan penanganan pasien kegawatdaruratan obstetrik dan neonatal (Kemenkes RI,2012). Pada saat wawancara mendalam pada pelaksanaannya SPO di rumah sakit belum seragam sehingga perlu dilakukan evaluasi kembali terhadap SPO yang belum seragam. Ditemukan juga ketidaksesuaian SOP dengan fasilitas yang ada di rumah sakit sehingga pihak rumah sakit telah melakukan pembahasan ulang dan penyusunan SPO yang baru disesuaikan dengan ketersediaan fasilitas di rumah sakit. Pedoman PONEK dan SPO yang ada telah disosialisasikan kepada seluruh staf yang terkait.

Kebijakan untuk mendukung penyelenggaraan PONEK di rumah sakit bertujuan agar program PONEK dapat terlaksana dengan baik. Sesuai dengan kriteria manajemen dalam pedoman penyelenggaraan PONEK 24 jam di rumah sakit, disebutkan bahwa Direktur RS melaksanakan komitmen untuk menyelenggarakan program PONEK menyelaraskan program RS untuk mendukung program PONEK dalam bentuk SK Direktur (Kemenkes RI, 2012). Sesuai dengan hasil observasi dan wawancara mendalam yang dilakukan oleh peneliti, baik RSU Puri Raharja maupun RSU Prima Medika telah tersedia kebijakan Direktur RS dalam bentuk SK Pembentukan Tim PONEK dan SK Pemberlakuan Pedoman Penyelenggaraan PONEK 24 Jam di Rumah Sakit. Bentuk komitmen lainnya dengan menyediakan dana untuk pemenuhan sarana dan prasarana secara bertahap serta melaksanakan peningkatan kapasitas PONEK bagi SDM di rumah sakit.

\section{SIMPULAN}

Secara keseluruhan ketersediaan input di RSU Swasta di Kota Denpasar telah mencukupi untuk 
menyelenggarakan PONEK di rumah sakit. Tim PONEK yang ada baru memenuhi kriteria tim essensial. Selain itu Tim PONEK yang ada di rumah sakit belum tersedia dalam setiap shift. Kemudian belum semua SDM dalam tim PONEK telah terlatih PONEK, tetapi SDM yang masuk ke dalam Tim PONEK telah memperoleh pelatihan penanganan kegawatdaruratan obstetri dan neonatus serta kegawatdaruratan umum seperti BLS,ATLS,ACLS.

Di RSU Prima Medika dan RSU Puri Raharja telah tersedia dana untuk menunjang penyelenggaraan PONEK. Ketersediaan dana digunakan untuk peningkatan kapasitas SDM dan pemenuhan sarana dan prasarana. Sarana dan prasarana di RSU Swasta di Kota Denpasar masih kurang terutama belum adanya ruang stabilisasi dan observasi obstetri di UGD. Kendala pemenuhan sarana dan prasarana di RSU Swasta di Kota Denpasar terkait dengan keterbatasan lahan dan dana. Untuk mengatasi keterbatasan tersebut, sarana dan prasana yang masih kurang telah direncanakan secara bertahap.

Pedoman penyelenggaraan PONEK 24 jam dan SPO penanganan kegawatdaruratan obstetri dan neonatus sudah ada di rumah sakit dan sudah disosialisasikan baik secara formal maupun informal. Kebijakan pendukung penyelenggaraan PONEK telah tersedia. Wujud komitmen pimpinan yakni dengan membentuk Tim PONEK yang dituangkan dalam bentuk SK Direktur RS tentang Pembentukan Tim PONEK Rumah Sakit.

\section{DAFTAR PUSTAKA}

Afiyanti,Y.(2014).Metodelogi Penelitian Kualitatif dalam Studi Keperawatan. Depok:Rajagrafindo Persada.

Ayuningtyas,D. (2014). Kebijakan Kesehatan:Prinsip dan Praktik. Jakarta: Rajawali Pers

Buse dkk. (2005). Health Policy Framework (Bab 1) dalam Making Health Policy.

Destiana,T. (2012). Analisis Implementasi Kebijakan Pelayanan Obstetri Neonatal Emergency Komprehensif (PONEK) di RSUD Kota Semarang,Skripsi. Universitas Diponegoro.

Kemenkes RI. (2009). Undang-undang nomor 44 tahun 2009 tentang Rumah Sakit. Jakarta:Kementerian Kesehatan RI.

Kemenkes RI. (2011). Standar Akreditasi Rumah Sakit. Jakarta:Kementerian Kesehatan RI.

Kemenkes RI. (2012). Pedoman Penyelenggaraan PONEK $24 \mathrm{Jam}$ di Rumah Sakit. Jakarta:Kementerian Kesehatan RI.

Ma'rifah,dkk. (2013). Evaluasi Pelaksanaan Kebijakan PONEK di Rumah Sakit Khusus Daerah Ibu dan Anak Siti Fatimah Kota Makassar Tahun 2013.p112

Permatasari,E. (2013). Implementasi Kebijakan Pelayanan Obstetri Neonatal Emergency Komprehensif RSUP DR Wahidin Sudirohusodo Makassar Tahun 2013.P1-P14. 
Saryono. (2011). Metode Penelitian Kesehatan:Penuntun Praktis Bagi Pemula. Jakarta: Alfabeta.

Simbolon,dkk. (2011). Determinan Kinerja Pelayanan Kesehatan Ibu dan Anak di Rumah Sakit Pemerintah Indonesia (Analisis Data Rifakes 2011). Jurnal Kebijakan Kesehatan Indonesia, Vol. 02, p.202-214.

Sugiyono. (2012). Metode Penelitian Kuantitatif. Bandung:Alfabeta

Sutjipta,I.N. (2009). Manajemen Sumber Daya Manusia. Denpasar:Universitas Udayana.
Notoadmojo,S. (2011). Kesehatan Masyarakat:Ilmu dan seni. Jakarta: Rineka Cipta.

Muninjaya,A.A.G. (2004). Manajemen Kesehatan. Jakarta: Penerbit Buku Kedokteran EGC. 